\title{
Reformulation of two Ni( II)-8-hydroxyquinoline Complexes from Calculated Structure Factors
}

\author{
Ng Seikweng Hu Sheng-Zhi ${ }^{1}$ \\ (Institute of Postgraduate Studies, University of Malaya \\ versity, Xiamen 361005, China) \\ 50603 Kuala Lumpur, Malaysia;
}

${ }^{1}$ Department of Chemistry, Xiamen Uni-

\begin{abstract}
The compound that had been crystallographically identified as $\mathrm{Na}\left[\mathrm{NiQ}_{2}(\mathrm{HQ})\right]\left(\mathrm{ClO}_{4}\right)$ ( $\mathrm{HQ}=8$-hydroxyquinoline ) contains no sodium, and instead is $\left[\mathrm{H}_{3} \mathrm{O}\right]\left[\mathrm{NiQ}_{2}(\mathrm{HQ})\right]\left(\mathrm{ClO}_{4}\right)$. The lanthanum-nickel complex $\left[\mathrm{YQ}(\mathrm{HQ})_{2}\right]$ $\left[\mathrm{NiQ}_{3}\right]\left(\mathrm{ClO}_{4}\right)$ that had been similarly identified contains no yttrium, and its formula is $\left[\mathrm{H}_{3} \mathrm{O}\right]\left[\mathrm{Ni}_{2} \mathrm{Q}_{3}(\mathrm{HQ})_{3}\right]\left(\mathrm{ClO}_{4}\right)_{2}$. The revision of the description of the crystal structures was effected by an examination of the bond dimensions that were derived by calculating the structure factors from the published atomic coordinates.
\end{abstract}

Keywords: Structure revision, Nickel(II) complex, Calculated structure factors

The reaction of nickel chloride, gadolinium perchlorate and 8-hydroxyquinoline in the presence of sodium $t$-butylacetate in water was reported to yield the six-coordinate compound, $\mathrm{Na}\left[\mathrm{NiQ}_{2}(\mathrm{HQ})\right]\left(\mathrm{ClO}_{4}\right)$ (1), whose structure was determined by crystallography. The compound belongs to the monoclinic $P 2 / n$ space group $[a=1.3546(7), b=1.2146(6), c=$ 1. $\left.6421(7) \mathrm{nm}, \beta=101.02(4)^{\circ}\right]$, and there are four formula units in the unit cell ${ }^{[1]}$. A similar reaction with yttrium perchlorate was claimed to afford the lanthanum-nickel complex $\left[\mathrm{YQ}(\mathrm{HQ})_{2}\right]\left[\mathrm{NiQ}_{3}\right]\left(\mathrm{ClO}_{4}\right)$ (2) $\left[P 2_{1} / c, a=1.6972(4), b=1.1128(3), c=\right.$ 2. $\left.2615(4) \mathrm{nm}, \beta=103.16(2)^{\circ}\right]^{[2]}$. However, the published bond distances involving the yttrium atom could not be independently verified from the atomic coordinates, although, curiously, the corresponding bond angles could be easily derived from the table. The rare six-coordinate status of the yttrium atom as well as the fact that the bond distances (calculated from the atomic coordinates) are not significantly different from those involving the nickel atom cast doubts on the au- thenticity of the structural determination. Indeed, if the yttrium(III) atom is replaced by a nickel(II) atom, the bond dimensions are normal, and the resulting formulation can also be reasonably expected of the synthesis; in the earlier reaction with gadolinium perchlorate, the lanthanum atom was not incorporated in the structure. These two crystal structures are re-interpreted and reformulated in this communication from the calculated structure factors for lack of original intensity data.

\section{Calculations}

The published table of atomic coordinates for (1) lists one sodium atom, one nickel atom, three quinolinolyl groups and one perchlorate group. The perchlorate group lies on the crystallographic two-fold axis; however, three oxygen atoms are bonded to the chlorine atom, two in general positions and one $(\mathrm{O} 12)$ in a special position. Since the perchlorate ion has four oxygen atoms, atom $\mathrm{O} 12$ should be omitted from the table. More importantly, because the ion lies on a 
two-fold axis, only two anions are present in the unit cell. A SHELX type of input file was then prepared that was checked by PLATON ${ }^{[3]}$ to ascertain the position of the other missing perchlorate group that would contribute two more perchlorate ions.

A SHELX type of input file was similarly prepared for (2). As the bond dimensions of the quinolinoly groups are unsatisfactory, the $h k l-F^{2}$ data were calculated $^{[4]}$ for the $0 \sim 50^{\circ} 2 \theta$ range; Mo- $K_{\alpha}$ radiation ( $\lambda=0.07107 \mathrm{~nm})$ was assumed in the calculations ${ }^{[5]}$, and all atoms were given a temperature factor of $0.0005 \mathrm{~nm}^{2}$. The perchlorate group was excluded in the computations, and a nickel atom was used in place of the yttrium atom. The structure was refined on $F^{2}$, and the quinolinyl groups were restrained into naphthalene groups by an AFIX 116 instruction. For the quinolinolyl groups, the $\mathrm{C}-\mathrm{O}$ and $\mathrm{N} \cdots \mathrm{O}$ interactions were restrained by SADI instructions in SHELXL-97 $7^{[6]}$.

\section{Discussion}

The program PLATON found two symmetry-related voids of $0.172 \mathrm{~nm}^{3}$ in the unit cell of (1). Most probably, the perchlorate group is to be found at $(1 / 4,-0.152,3 / 4)$. In the nickel bearing moiety, the $\mathrm{O} 1$ oxygen atom is $0.2345 \mathrm{~nm}$ from the $\mathrm{O} 2$ atom of a symmetry related moiety, so that these two atoms must linked by a hydrogen bond; arising from this interaction, the molecule probably has only one neutral HQ entity. The sodium atom is linked to only two oxygen atoms ( $\mathrm{O} 3$ and the symmetry-related $\mathrm{O} 3 i$ atoms) at $0.2935 \mathrm{~nm}$. More likely, the sodium atom is an oxygen atom, and the ion would be the hydronium $\left[\mathrm{H}_{3} \mathrm{O}\right]^{+}$ cation that contributes one symmetry-independent hydrogen atom for bonding with the O3 oxygen atom, which bears a formal negative charge for the quinolinolyl group that it belongs to. The second hydronium cation is most probably found at $(1 / 4,0.582,3 / 4)$. Balancing the charges leads to the conclusion that the nickellate would be the $\mathrm{Na}\left[\mathrm{NiQ}_{2}(\mathrm{HQ})\right]$ mono-cation. The correct structure of (1) is then $\left[\mathrm{H}_{3} \mathrm{O}\right]\left[\mathrm{NiQ}_{2}(\mathrm{HQ})\right]$ $\left(\mathrm{ClO}_{4}\right)$. The calculated $\mathrm{CHN}$ elemental percentages for the revised fomulation are in reasonably good agree- ment with the reported values. Table 1 lists a partial list of the atomic coordinates of the revised structure. The quinolinyl group has been restrained to have idealized distances and angles; the structure of the mono-cation is shown in Fig. 1.

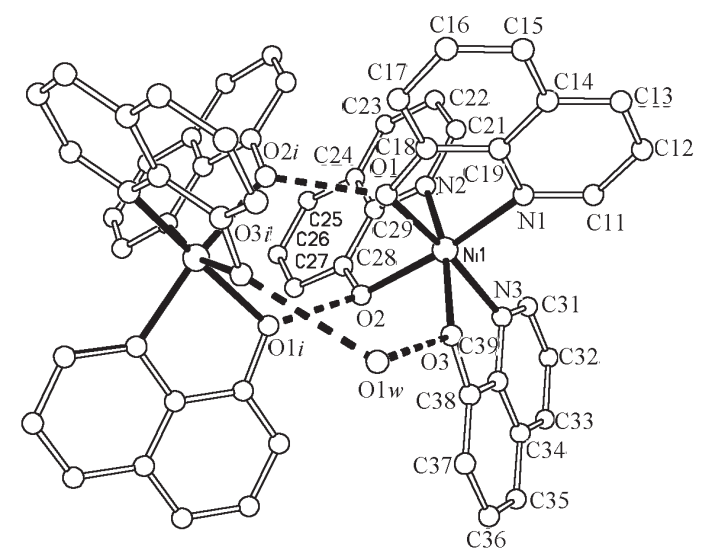

Fig. 1 Plot of the $\left[\mathrm{H}_{3} \mathrm{O}\right]\left[\mathrm{NiQ}_{2}(\mathrm{HQ})\right]$ cation of $\left[\mathrm{H}_{3} \mathrm{O}\right]$ $\left[\mathrm{NiQ}_{2}(\mathrm{HQ})\right]\left(\mathrm{ClO}_{4}\right)$.

The hydronium ion is represented by the $\mathrm{Olw}$ atom. The dashed lines denote hydrogen bonds: $\mathrm{O} 1 \cdots \mathrm{O} 2 i=0.2345$ $\mathrm{nm}, \mathrm{O} 1 w^{\cdots \mathrm{O}} 3=\mathrm{O} 1 w^{\cdots \mathrm{O}} 3 i=0.2953 \mathrm{~nm}$. Symmetry code: $i=1 / 2-x, y, 1 / 2-z$

The reported structure of (2) is marked by several chemical and crystallographic inconsistencies, but these could be reasonably explained if the yttrium atom is, in fact, a nickel atom. The second perchlorate group, omitted from the table of atomic coordinates, is most probably to be found at $(0.166,-0.0065,0.204)$. The two nickellate octahedra are linked through their oxygen vertices by three hydrogen bonds, which suggests the existence of the dinuclear $\left[\mathrm{Ni}_{2} \mathrm{Q}_{3}(\mathrm{HQ})_{3}\right]^{+}$monocation. Because there are two perchlorate groups, one of which had been calculated by PLATON, the charges of the cations and ions would be balanced if a hydronium cation exists in the crystal structure. Unfortunately, the cell is too large for this to be located, although the program did reveal several solvent-accessible voids. On the basis of these voids, (2) is reformulated as $\left[\mathrm{H}_{3} \mathrm{O}\right]$ $\left[\mathrm{Ni}_{2} \mathrm{Q}_{3}(\mathrm{HQ})_{3}\right]\left(\mathrm{ClO}_{4}\right)_{2}$. The bands in the infrared spectrum are also in agreement with the presence of water, although the authors had interpreted these ${ }^{[2]}$ in terms of 
Table 1 Atomic coordinates for the $\left[\mathrm{H}_{3} \mathrm{O}\right]\left[\mathrm{NiQ}_{2}(\mathrm{HQ})\right]$ cation of $\left[\mathrm{H}_{3} \mathrm{O}\right]\left[\mathrm{NiQ}_{2}(\mathrm{HQ})\right]\left(\mathrm{ClO}_{4}\right)$

in $P 2 / n\left[a=1.3546(7), b=1.2146(6), c=1.6421(7) \mathrm{nm}, \beta=101.02(4)^{\circ}\right]$

\begin{tabular}{cccccccc}
\hline Atom & $X$ & $Y$ & $Z$ & Atom & $X$ & \multicolumn{1}{c}{$Y$} & Z \\
\hline Ni1 & 0.2609 & 0.2514 & 0.0994 & C22 & 0.1648 & -0.0870 & 0.0260 \\
O1 & 0.1485 & 0.2752 & 0.1666 & C23 & 0.2293 & -0.1443 & 0.0876 \\
O2 & 0.3576 & 0.1975 & 0.2036 & C24 & 0.2965 & -0.0872 & 0.1474 \\
O3 & 0.3157 & 0.4126 & 0.1343 & C25 & 0.3609 & -0.1444 & 0.2090 \\
N1 & 0.1510 & 0.3039 & 0.0057 & C26 & 0.4281 & -0.0873 & 0.2688 \\
N2 & 0.2347 & 0.0844 & 0.0840 & C27 & 0.4308 & 0.0270 & 0.2670 \\
N3 & 0.3816 & 0.2641 & 0.0389 & C28 & 0.3664 & 0.0842 & 0.2054 \\
O1w & $1 / 4$ & 0.5704 & $1 / 4$ & C29 & 0.2992 & 0.0271 & 0.1456 \\
C11 & 0.1533 & 0.3174 & -0.0779 & C31 & 0.4132 & 0.1871 & -0.0131 \\
C12 & 0.0677 & 0.3524 & -0.1325 & C32 & 0.5080 & 0.1960 & -0.0331 \\
C13 & -0.0202 & 0.3738 & -0.1034 & C33 & 0.5713 & 0.2820 & -0.0009 \\
C14 & -0.0225 & 0.3602 & -0.0197 & C34 & 0.5398 & 0.3591 & 0.0511 \\
C15 & -0.1104 & 0.3816 & 0.0093 & C35 & 0.6030 & 0.4451 & 0.0833 \\
C16 & -0.1127 & 0.3680 & 0.0930 & C36 & 0.5715 & 0.5221 & 0.1355 \\
C17 & -0.0271 & 0.3331 & 0.1475 & C37 & 0.4766 & 0.5132 & 0.1554 \\
C18 & 0.0608 & 0.3117 & 0.1185 & C38 & 0.4133 & 0.4272 & 0.1233 \\
C19 & 0.0631 & 0.3253 & 0.0348 & C39 & 0.4449 & 0.3501 & 0.0711 \\
C21 & 0.1675 & 0.0273 & 0.0242 & & & & \\
\hline
\end{tabular}

the $\mathrm{OH}$ stretching of the neutral HQ groups.

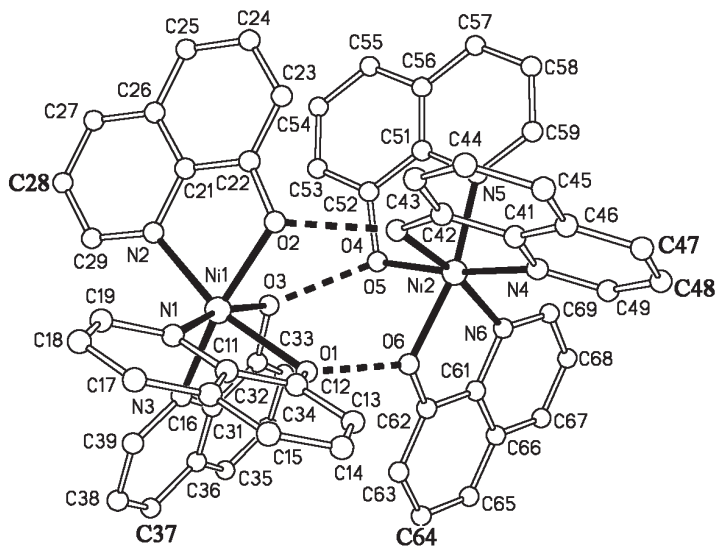

Fig. 2 Plot of the $\left[\mathrm{Ni}_{2} \mathrm{Q}_{3}(\mathrm{HQ})_{3}\right]$ cation of $\left[\mathrm{H}_{3} \mathrm{O}\right]\left[\mathrm{Ni}_{2} \mathbf{Q}_{3}\right.$ $\left.(\mathrm{HQ})_{3}\right]\left(\mathrm{ClO}_{4}\right)_{2}$.

The dashed lines denote hydrogen bonds: $\mathrm{O} 1 \cdots \mathrm{O} 6=0.2212$ $\mathrm{nm}, \mathrm{O}_{2} \cdots \mathrm{O}_{4}=0.2294 \mathrm{~nm}, \mathrm{O} 3 \cdots \mathrm{O} 5=0.2381 \mathrm{~nm}$.
The reported distances and angles for the yttrium atom in (2) make little sense as the valence sum $^{[7]}$ are too large; however, the valence sum is reasonable if the atom is calculated as nickel. Indeed, bond valence sums have been used for studying the coordination geometries of a number of transition metal complexes ${ }^{[8]}$. The formulation of (2) is also supported by other crystallographically documented dinickel / quinolinol systems $^{[9-11]}$.

In a crystallographic report, any bond dimension can be easily calculated from the cell constants, space group information and atomic coordinates, but this is possible only if the coordinates of all non-hydrogen atoms are published. The omission of the important atoms from the table could lead to an incorrect formulation. 
Table 2 Atomic coordinates for the $\left[\mathrm{Ni}_{2} \mathbf{Q}_{3}(\mathrm{HQ})_{3}\right]$ cation of $\left[\mathrm{H}_{3} \mathrm{O}\right]\left[\mathrm{Ni}_{2} \mathbf{Q}_{3}(\mathrm{HQ})_{3}\right]\left(\mathrm{ClO}_{4}\right)_{2}$ in $P 2_{1} / c$ [ $\left.a=1.6972(4), b=1.4128(3), c=1.4128(3) \mathrm{nm}, \beta=103.16(2)^{\circ}\right]$

\begin{tabular}{|c|c|c|c|c|c|c|c|}
\hline Atom & $X$ & $Y$ & $Z$ & Atom & $X$ & $Y$ & $Z$ \\
\hline $\mathrm{Nil}$ & 0.1717 & 0.2810 & 0.3477 & C 33 & 0. 1129 & 0.4277 & 0. 1721 \\
\hline $\mathrm{Ni} 2$ & 0. 4068 & 0.3585 & 0. 2805 & C 34 & 0.0520 & 0.4072 & 0. 1212 \\
\hline $\mathrm{O} 1$ & 0.2446 & 0. 1939 & 0.3032 & C35 & -0.0018 & 0.3338 & 0. 1232 \\
\hline $\mathrm{O} 2$ & 0.2827 & 0.3244 & 0.4035 & C36 & 0.0051 & 0.2809 & 0.1760 \\
\hline O3 & 0.1782 & 0. 3892 & 0. 2809 & C37 & -0.0487 & 0.2075 & 0.1780 \\
\hline $\mathrm{O} 4$ & 0.3976 & 0.3132 & 0. 3667 & C38 & -0.0417 & 0. 1547 & 0.2307 \\
\hline $\mathrm{O} 5$ & 0.3079 & 0.4419 & 0.2711 & C39 & 0.0191 & 0. 1752 & 0.2816 \\
\hline O6 & 0.3264 & 0.2522 & 0. 2488 & $\mathrm{C} 41$ & 0.5261 & 0.2450 & 0. 3632 \\
\hline N1 & 0.1665 & 0. 1578 & 0.3988 & $\mathrm{C} 42$ & 0.4680 & 0.2630 & 0. 3964 \\
\hline N2 & 0. 1286 & 0.3840 & 0.3980 & $\mathrm{C} 43$ & 0.4787 & 0.2289 & 0.4553 \\
\hline N3 & 0.0730 & 0.2486 & 0.2796 & $\mathrm{C} 44$ & 0.5473 & 0.1767 & 0.4811 \\
\hline N4 & 0.5154 & 0.2791 & 0.3043 & $\mathrm{C} 45$ & 0.6054 & 0.1587 & 0. 4480 \\
\hline N5 & 0.4678 & 0.4791 & 0.3216 & $\mathrm{C} 46$ & 0.5947 & 0. 1928 & 0. 3890 \\
\hline N6 & 0.4046 & 0.3838 & 0. 1864 & $\mathrm{C} 47$ & 0.6528 & 0.1748 & 0. 3559 \\
\hline $\mathrm{C} 11$ & 0.2191 & 0.0905 & 0.3847 & $\mathrm{C} 48$ & 0.6421 & 0. 2089 & 0. 2970 \\
\hline $\mathrm{C} 12$ & 0.2620 & 0. 1098 & 0.3405 & $\mathrm{C} 49$ & 0.5735 & 0.2611 & 0.2712 \\
\hline $\mathrm{C} 13$ & 0.3145 & 0.0425 & 0.3264 & C51 & 0.4104 & 0.5427 & 0. 3328 \\
\hline $\mathrm{C} 14$ & 0.3242 & -0.0440 & 0.3564 & $\mathrm{C} 52$ & 0.3285 & 0.5229 & 0.3126 \\
\hline $\mathrm{C} 15$ & 0.2813 & -0.0633 & 0.4005 & C53 & 0.2711 & 0.5865 & 0.3238 \\
\hline $\mathrm{C} 16$ & 0.2288 & 0.0039 & 0.4147 & C54 & 0. 2957 & 0.6698 & 0.3553 \\
\hline $\mathrm{C} 17$ & 0. 1859 & -0.0152 & 0.4589 & $\mathrm{C} 55$ & 0.3776 & 0.6896 & 0.3755 \\
\hline $\mathrm{C} 18$ & 0. 1333 & 0. 0520 & 0.4730 & C56 & 0.4350 & 0.6261 & 0.3643 \\
\hline C19 & 0. 1237 & 0. 1385 & 0.4430 & $\mathrm{C} 57$ & 0.5170 & 0.6458 & 0.3845 \\
\hline $\mathrm{C} 21$ & 0. 1922 & 0.4379 & 0.4309 & C58 & 0.5743 & 0.5823 & 0.3733 \\
\hline $\mathrm{C} 22$ & 0.2716 & 0.4131 & 0.4314 & C59 & 0. 5498 & 0.4989 & 0.3418 \\
\hline $\mathrm{C} 23$ & 0.3352 & 0.4671 & 0.4643 & C61 & 0.3453 & 0.3241 & 0.1537 \\
\hline $\mathrm{C} 24$ & 0.3194 & 0.5458 & 0.4965 & $\mathrm{C} 62$ & 0.3029 & 0.2642 & 0. 1841 \\
\hline $\mathrm{C} 25$ & 0.2400 & 0.5706 & 0.4960 & C63 & 0.2436 & 0.2045 & 0. 1514 \\
\hline $\mathrm{C} 26$ & 0.1764 & 0.5167 & 0.4631 & C64 & 0.2267 & 0.2047 & 0. 0883 \\
\hline $\mathrm{C} 27$ & 0.0970 & 0.5415 & 0.4626 & C65 & 0.2691 & 0.2646 & 0.0579 \\
\hline $\mathrm{C} 28$ & 0.0334 & 0.4876 & 0.4297 & C66 & 0.3284 & 0.3243 & 0.0906 \\
\hline $\mathrm{C} 29$ & 0.0492 & 0. 4088 & 0. 3975 & C67 & 0. 3708 & 0. 3842 & 0. 0602 \\
\hline C31 & 0.0660 & 0.3015 & 0. 2268 & C68 & 0.4301 & 0.4439 & 0. 0929 \\
\hline $\mathrm{C} 32$ & 0.1199 & 0. 3749 & 0.2248 & $\mathrm{C} 69$ & 0.4470 & 0.4437 & 0.1560 \\
\hline
\end{tabular}




\section{References}

1 Zhang M J, Huang C H, Xu G X. Post Doctoral Theses of China, Peking University Press, 1990, 181

2 Zhang M J, Huang C H, Xu G X. Chem. J. Chin. Univs., 1990, 11: 1313

Ng S W, Rae A D. Z. Kristallogr., 1999, 214: 383

Oxford Cryosystems. J. Appl. Crystallogr., 1996, 29: 306

Sheldrick G M. SHELXL-97. Program for the Refinement of

Crystal Structures. University of Göttingen, Germany, 1997

6 Spek A L. Acta Crystallogr., 1990, A46: C-34
7 Zhou G D. Elements of Structural Chemistry (in Chinese). Beijing: Peking University Press, 1989, 419

8 Palenik G J. Inorg. Chem., 1997, 36: 3394

9 Kiriyama H, Fukuda T, Yamagata, et al. Acta Crystallogr., 1985, C41: 1441

10 Kiriyama H, Yamagata Y, Yonetani K, et al. Acta Crystallogr., 1986, C42: 56

11 Kiriyama H, Yamagata Y, Suzuki K. Acta Crystallogr., 1986, C42: 785

\title{
根据计算结构因子重新指定镍 (II)8- 羟基喹啉的两个络合物
}

\author{
$\mathrm{Ng}$ Seikweng \\ (马来亚大学研究生院，50603 Kuala Lumpur, 马来西亚) \\ 胡盛志 \\ (厦门大学化学系,厦门 361005)
}

摘要 晶体学研究曾认为, 分子式是 $\mathrm{Na}\left[\mathrm{NiQ}_{2}(\mathrm{HQ})\right]\left(\mathrm{CLO}_{4}\right)$ 的结构并不含有钠而应为 $\left[\mathrm{H}_{3} \mathrm{O}\right]\left[\mathrm{NiQ}_{2}(\mathrm{HQ})\right]$ $\left(\mathrm{CLO}_{4}\right)$. 相似地, 稀土 $-\mathrm{Ni}$ 络合物 $\left[\mathrm{YQ}(\mathrm{HQ})_{2}\right]\left[\mathrm{NiQ}_{3}\right]\left(\mathrm{CLO}_{4}\right)$ 也不含有钎而应为 $\left[\mathrm{H}_{3} \mathrm{O}\right]\left[\mathrm{Ni}_{2} \mathrm{Q}_{3}(\mathrm{HQ})_{3}\right]$ $\left(\mathrm{CLO}_{4}\right)$. 晶体结构描述的修正系根据文献报导的原子坐标计算结构因子所导出的结果 .

关键词：结构修正，镍 (II)络合物，计算结构因子 